\title{
International Cooperation as a Tool in Counterterrorism: Then and Now
}

\author{
By Sebastian L. v. Gorka
}

In the decade following the fall of the Berlin Wall, the dissolution of the Warsaw Pact, and the collapse of the USSR, there followed a flurry of attempts at describing what the post-Cold War order would be. The lack of certainty was reflected in the variety of scenarios presented. Typically, in a fashion that reflected the rigidity of thought prevalent during the Cold War years, the first attempts concentrated on the identification of new poles to replace the dual superpower poles of the previous decades. Among the alternatives to the bipolar balance of the United States versus the USSR, were a unipolar order (United States alone), a tripolar order (United States, Europe, Japan), and various multipolar variations. Beyond these simplistic options, there developed more holistic and nuanced propositions. Perhaps the two most famous theories or visions were those of the conservative academic Francis Fukuyama and the doyen of nation-state security studies, Samuel P. Huntington. In the early nineties both attempted to give a new overarching appraisal of the coming geostrategic reality. Fukuyama ingeniously entitled his theory with the sufficiently provocative title The End of History. While obviously meant to be a controversial title, the thesis itself was less so. The argument essentially was that the twentieth century could be typified by the attempts of two extreme ideologies to destroy the "market democracy" model of state administration: Nazism and Communism. The fact that both were defeated 1 by the last decade of the century meant that democracy had been victorious and thus there was "no new history to write."

Huntington's vision, as declared in his article and book Clash of Civilizations, was a far darker one. His prediction was that the age of conflicts between nationstates, or alliances of nation-states, would be replaced by an era of conflicts arising between cultures, or civilizations, or along the divides between them, a harking back to more medieval divisions. Wars in this new (or revisited old) age would be caused, or at least exacerbated, by poverty differentials between North and South, West and East, as well as by religious fundamentalism. ${ }^{3}$

1 Of course, there were and remain exceptions: communist regimes outside of the immediate vicinity of Europe, including North Korea, Cuba, Vietnam, and China.

2 Francis Fukuyama, The End of History and the Last Man (New York: Avon Books, 1992).

3 Samuel Huntington, The Clash of Civilizations and the Remaking of World Order (New York: Simon and Shuster, 1996). 
Since their publication, these theories have prompted much criticism as well as comment. Perhaps most strikingly, their effect upon thinking relating to "hard security" issues was minimal. The question of what impact such theories would or should have-if proven valid - upon the exercise of national security was conspicuous by its absence. This in part has to do with the confusing nature of threat assessment in the period following 1990 and prior to September 2001.

\section{The Cornucopia of Threats: A Challenge to Prioritization}

Perhaps only after the fact did it become apparent to the national security community within the western community of "market democracies" that the Cold War had been an eminently workable international system. While the overarching threat-Mutually Assured Destruction (MAD) — was ultimate in scale, potentially ensuring for the annihilation of both East and West should World War III have happened, the fact was that the bloc-to-bloc arms race, perceived near parity, and the later developed system of arms negotiations and arms control regimes, together resulted in a system that was for the most part well-balanced and predictable. ${ }^{4}$ For those with responsibilities within the national security architectures of the western nations, the enemy and the related responsibilities were quite clear: (1) the USSR, its allies; (2) the prevention of WWIII (or, should that not be possible, preparation to win the "hot war"). The enemy(-ies) was a static nation-state, with easily identified points of gravity such as its capital, its industrial base, and its organs of security and defense. How to "take the Cold War" to these targets was relatively obvious, if not easy.

Beyond this overarching challenge, there was, of course, another national security-related task-set: terrorism. From the 1960s onwards countries such as the UK, Spain, Germany, and Italy, as well as several nations in Latin America, had to fight the scourge of political violence. However, here it is important to note that in comparison to the primary threat posed by the Soviet bloc, this enemy was in a fundamentally different class. Whichever group one cares to choose, be it the Baader-Meinhof Gang, Basque Fatherland and Liberty (ETA), or the Provisional Irish Republican Army (PIRA), while deadly, none had the capacity to strike a fatal blow against the government they were fighting, and thus they did not vitally endanger the given nation's existence as did the Soviet Union.

With the fall of the Iron Curtain, national security faced a new challenge. As the Soviet Union dissolved into several nations and the biggest, the Russian Federation,

4 Perhaps the two most obvious points at which the Cold War could have metastasized into a "hot war" were the Korean War of 1950 and the Cuban missile crisis of 1962. These represent just two events in a span of forty years, a ratio that underlines the fundamental stability of Cold War bipolarity. 
established normalized relations with the North Atlantic Treaty Organization (NATO) and would even become nominally an ally in later years, ${ }^{5}$ other new or newly revitalized threats emerged to challenge western governments and concurrent domestic calls for a post-Cold War peace dividend. These threats ranged from the familiar, such as failed states, to the new and outré, such as information warfare and critical infrastructure defense. (For Detailed Information Please See Original Version of this Article.)

As the number and nature of the new panoply of threats and challenges grew and became more complicated, two obvious questions arose. The first was, given the limits to defense expenditure that exist in most democracies, how should governments now prioritize their national security investments and activities? Which of the enumerated threats should receive greater attention, where should limited public resources be invested so as to best protect the population and the national interests? For many nations the answer was not clear. The second question had to do with capabilities.

In the European half of the Atlantic Alliance defense and security capabilities were very much shaped, understandably, with the scenario of WWIII in mind. The national war-planners and the multinational staffs at Supreme Headquarters Allied Powers Europe (SHAPE) in Belgium worked on the assumption that should conflict erupt the USSR and its satrapies would execute a massive land attack against the West through the Sibbesse Gap into West Germany and beyond, most likely using chemical weapons, before resorting to tactical nuclear weapons if necessary. It was NATO's raison d'être to ensure that the United States would respond to the overwhelming conventional advantage posed by the 2 nd Red Army by bringing an intercontinental and intermediate nuclear response to such a land attack. Subsequently, the majority of forces in the European half of NATO were designed to fulfill a largely static territorial defense function, to act as a delaying force inhibiting the rapid invasion of Soviet forces until the transatlantic nuclear response was made. In layman's terms this meant that the armies of most western nations were replete with heavy, slow armor and antiarmor assets ${ }^{6}$ fit for nation-on-nation conventional, or Clausewitzian war.

It soon became apparent that the appropriateness of such capabilities was limited in a new threat environment, which included the requirement that a nation be able to project its forces far further afield than its own national territory. As a result, very

5 This is especially true in formal terms with the creation of the Permanent NATO-Russia Permanent Joint Council (PJC) in 2001 and especially after President Putin's adroit manipulation of the post-9/11 situation in the White House.

6 The exceptions to this rule - those nations with more flexible armed forces that could be deployed well beyond the nation's own borders - were, of course, those countries that had had strong imperial histories and still retained quasi-colonial interests. Such countries include the United Kingdom, France, and Belgium. 
soon talk of a growing gap between US and European defense capabilities increased, given that the United States, thanks to its geography and the way in which it defined its global interests, had at its disposal a far more flexible and projectable force than any of its allies.

\section{9/11: Clarity in Prioritization?}

While the second problem was a factual one that could not be explained away, or would not disappear by itself, the first dilemma regarding prioritization was solved, at least according to some members of the Western Alliance, with the aircraft attacks aimed at civilians on one fall day in 2001.

Among professional students of political violence, there are few scholars who have been able to turn theoretical observations into policy-relevant products. Brian Jenkins, of the RAND Corporation, is one of them. One of his most famous observations - which has since become conventional wisdom within the field-was that "The terrorist doesn't want a lot of people dead. He wants a lot of people watching."” The inference, of course, is that the heart of terrorism is the desire to inculcate fear in a population and that in the modern age the media have become one of the most prized weapons of the terrorists, since they enable terrorists to further a message of fear to as wide an audience as possible. And in the era of regular hijackings, political assassinations, and high-exposure events such as the 1975 attack in Austria on the OPEC ministers, or the 1972 murder of members of the Israeli Olympic team in $\mathrm{Mu}-$ nich, this adage was proven again and again. However, trends in the 1990s and 9/11 itself seem to point — at least for some observers - to a new, even more frightening trend.

The first observation regarding this new trend is a purely statistical one. Every year the US Department of State publishes a report on the previous year's terrorist attacks against American targets. ${ }^{8}$ After the prose description of the year's events and those involved, each report contains a series of appendices detailing the names of terrorist groups and mathematical data related to the attacks described. While the publication is admittedly not a comprehensive assessment of all terrorist activities in

7 Jenkins, Brian. International Terrorism: A New Mode of Conflict, Research Paper 48, California Seminar on Arms Control and Foreign Policy, Crescent Publications, Los Angeles, 1975. Near the end of the 1990s Mr. Jenkins publicly wrote that this theorum might be less and less true as the character of modern terrorism changed. He was correct - in both cases - in the editors' view.

8 For over two decades called Patterns of Global Terrorism, since 2005 this publication by the US Department of State is called Country Reports on Terrorism. Current and past reports are available at http://www.state.gov/s/ct/rls/crt/, accessed 11 September 2009. 
a given calendar year, focused as it is solely upon attacks executed against US interests, the changes identifiable over the twenty-four years that data have been collected have led to one clear conclusion being drawn. While the period since the end of the Cold War has seen a marked decrease in the frequency per year of successful attacks launched against the United States, the lethality of individual events has increased. In other words, more people are likely to die or be injured as the result of one single attack than would otherwise have been the case in previous (Cold War) years.

As a result of this trend, some commentators have extrapolated to conclude that Jenkins's famous observation no longer holds: While the size of audience was the driving factor in the past, now it is the extent of damage, the extent of killing that is more important ${ }^{9}$ to the terrorist. We have moved from mass-audience terrorism to mass-casualty terrorism. This has led to the hypothesis that there now exist terrorists who simply wish to kill as many people as possible, and to this end they will attempt to acquire weapons of mass destruction (WMD). This nascent category of actor has been christened the hyper-terrorist. ${ }^{10}$

There is, however, one superficial problem with this hypothesis, and that derives from the nature of modern terrorism we have become acquainted with in the latter half of the twentieth century. If the hypothesis is to work, in this author's opinion a differentiation must be made between at least two fundamental types of terrorist.

\section{Hyper-Terrorism and the Rational Versus the Irrational Actor}

One important common denominator among the vast majority of those sub-state actors that used political violence in previous decades was that the end-state they wished to achieve was at least theoretically possible. The classic terrorist groups, as typified by the PIRA and the Basque separatist group ETA, were predicated around clearly communicated demands for self-determination, or simply greater autonomy from the governing nation-state. As a result, while the concept of the counties of Northern

9 In addition to the triple attacks of 9/11, which left almost three thousand dead, the other (somewhat lesser) examples of such hyper-terrorism include the attack on the Alfred P. Murrah Federal Building complex in Oklahoma City in 1995, which killed almost two hundred; the 2004 train bombings in Madrid, which killed nearly two hundred and injured more than a thousand; and the 2005 London subway attacks, which killed twelve and wounded almost two hundred.

10 François Heisbourg, Europe and the Transformation of the World Order, prepared for the IISS/CEPS European Security Forum, Brussels, November 5, 2001, available at http:// www.eusec.org/heisbourg.htm, accessed 11 September 2009. Given that al Qaeda killed more people in 102 minutes on 9/11 than the PIRA did between 1968 and 1998, hyperterrorism seems to be an incontravertible description of a new phenomenon. 
Ireland being reunited with Eire, or the idea of a more independent Basque-land may have been anathema to the governments of London and Madrid, these were demands that could not be thought completely out of the question. Thus, differences between the given group and the relevant government were potentially resolvable via political means ${ }^{11}$ and not just demands to be mitigated solely by exposing such groups to lethal force or interdiction by law enforcement authorities.

It is exactly by dint of the feasible nature of the end-state demanded that such groups should quite rightly be deemed rational or pragmatic in their strategy and behavior. It is also clear, therefore, why such groups never resorted to strategies or weapons that would result in truly mass casualties. The end-state to be achieved was a worldly, political one. The "game plan" was to achieve a political victory by forcing a capitulation of the government on a specific issue thanks to the majority of the public exerting (through fear) adequate pressure to ensure for a change in said policy. Any act that resulted in mass casualty, resorting to WMD technology, for example, would rationally and predictably result in two consequences: the loss of all potential support from the elements of the larger population that were sympathetic to the broader goals of the group; and justification for the government to use all means (even shoot-to-kill tactics) to eradicate the terrorist group once and for all. Thus, it would seem that hyper-terrorism - the desire of terrorists to obtain and use WMD capabilities - cannot apply to a rationally thinking sub-state actor who has a feasible (political) end-state in mind. But if hyper-terrorism is an extant phenomenon, then to whom does it apply?

Perhaps the clearest, most scientifically discrete candidate for designation as the modern age's first specimen of hyper-terrorism is Aum Shinrikyo. This organization is infamous as being the first non-state actor to use a chemical weapon successfully against civilians. In 1995, after years of experimenting with both chemical and biological agents, ${ }^{12}$ the cult deployed a weak solution of sarin nerve agent on the Tokyo metro. We now know that the group had a very different end-state in mind from that witnessed in the case of "classic" pragmatic terrorist actors such as ETA or PIRA. Through a series of similar WMD attacks, the cult and its half-blind prophet-leader Shoko Asahara planned to take control of the government of Japan. Once it had es-

11 It is interesting here to note that, in spite of strident statements in the 1980s by Margaret Thatcher's government that the British administration would never negotiate with terrorists, thanks to the various memoirs that have since then been published, we now know that such UK government-PIRA talks did in fact take place repeatedly well before the Good Friday Accords. For more information on negotiating with terrorists, see the chapter by James Wither later in this volume.

12 Aum Shinrikyo even attempted biological attacks (unsuccessfully) prior to the Metro attack of 1995. 
tablished itself as the new government of Japan, the cult intended to unleash a global WMD campaign until it ruled the whole planet and could create a worldwide cultic religious state and then initiate End Times. It is clear that such an end-state is not politically feasible and that there is no political solution possible that would bring the cult and its enemies to a possible negotiated compromise. The scenario driving this sub-state actor was not a worldly one, infused as it was with apocalyptic aspects, and thus we may make a distinction in this case and classify Aum as a nonrational, or transcendentally informed, terrorist group. ${ }^{13}$

The identification of whether or not a given terrorist group has such a worldview, one where compromise with the government is not just unimportant but impossible and where a transcendental "reality" informs the actions of the perpetrator is significant beyond solely the realm of theory. The question of whether or not we are dealing with a rational or nonrational actor ${ }^{14}$ will have distinct implications upon what type of response government authorities can deploy. In the case of the former, the choice of tools is broad, ranging from military force and police action to secret or open negotiations and even third-party mediation or arbitration. If, however, the group is of the latter variety, then we are limited to two fundamental options: arresting or annihilating the terrorist group. Who the enemy is, therefore, dictates the modality of response.

\section{Categorizing the Current Threat: Al Qaeda}

It is clear that the 11 September 2001 attacks in New York, Washington, and Pennsylvania were designed to exact as many casualties as possible_-and most interestingly as regards methodology, to do so without resorting at all to WMD technology. But the question remains: What were the end-state and specific demands of the group responsible for 9/11? Here one needs to look at the communiqués and other items of propaganda disseminated by Osama bin Laden and high-ranking al Qaeda terrorists over the years.

13 Note that I am not using the word irrational, but nonrational, since there is a logic to the strategic thought of such a group, but it is one devoid of normal cost-benefit analysis since it is transcendentally informed.

14 The provocative strategist Ralph Peters makes a similar distinction between the practical and apocalyptic terrorist, but unfortunately limits his discussion of the latter to Muslim extremists, such as Osama bin Laden, when in fact the group is larger and should rightly include many non-Muslim and non-Arab groups, such as Aum Shinrikyo and potentially even Christian fundamentalists or other ethnically Caucasian groups such as the Branch Davidians. See Peters, Beyond Terror: Strategy in a Changing World (Mechanicsburg, PA: Stackpole Books 2002), especially Part I, "When Devils Walk the Earth"; and Sebestyén L. v. Gorka, "2000 AD: Boom Time in the Doom Market," Jane's Intelligence Review, January 2000. 
In the beginning, before al Qaeda ("the Base") became well known in the intelligence and academic communities, Osama bin Laden had taken control of the Arab Service Bureau of which he had been a part and which had recruited and trained many of the foreign mujahedeen who had fought against the Soviet troops of occupation in Afghanistan. At that time, the avowed aims of the new organization were clearly defined against the backdrop of a world seen in distinctly Huntingtonian and Manichean terms. For this fundamentalist fighter, by the early 1990s, having won the fight against the then "lead Satan" (the USSR), it was time to fight for oppressed Muslims everywhere and to take the fight to the, until then, secondary Satan: western civilization, led by the United States. The western world was and is seen by bin Laden as antithetical to his fundamentalist view of the Islamic faith, an affront to all that is good and holy and a force that through its soft power, capitalism and globalization, further weakens the hold of the Muslim system over its followers. The end-state depicted by the former mujahedeen is the re-creation of a caliphate, starting with the Middle East and Central Asia, but eventually spreading over the whole world as the West is systematically undermined over years and even decades through a campaign of asymmetric warfare that exploits the very aspects of the liberal democratic system of which its nations and leaders are so proud. In all this, since it is the standard-bearer of the liberaldemocratic, capitalist model, and the source of most that is unholy, the United States stands as the primary "western" target. ${ }^{15}$

As a result of such pronouncements and based upon interviews ${ }^{16}$ with captured or reformed members of the terrorist organization, one would be led understandably to the conclusion that al Qaeda fits quite neatly into the category of nonrational terrorist actor. No political resolution is even theoretically possible given the absolute and transcendentally informed nature of the desired state-of-affairs (a global caliphate) that al Qaeda wishes to achieve.

It should be noted, however, that since becoming a player on the world stage and after the more successful attacks that culminated in the events of 9/11, bin Laden has complicated matters by inserting other lower-level political demands into the broader palate of existing pronouncements. These have included the removal of US troops from the lands that contain the holiest of Muslim sites (such as Saudi Arabia) and, perhaps most pronounced, the demand made in the prerecorded video statement

15 An excellent collection of al Qaeda statements was compiled by the former Federal Broadcast Information Service (FBIS) and can be accessed by US government employees and contractors through the Open Source Center (which absorbed the FBIS) at https://www. opensource.gov/

16 For examples of information supporting this vision, see the various works by al Qaeda specialist Rohan Gunaratna, such as Inside Al Qaeda: Global Network of Terror (New York: Columbia University Press, 2002). 
that was released on the invasion of Afghanistan in which bin Laden stated that there would no peace in the West, nor in America, until there existed a free and independent Palestine. Both of these are feasible demands open to a political approach that fits very nicely into the rational terrorist category. In fact, one of them has already occurred.

Subsequently we are left with the problem of how to classify the threat posed by al Qaeda's version of hyper-terrorism. In my opinion, the conflation of nonrational with rational elements, of political with transcendentally informed goals, may in fact be a deliberate ploy on behalf of the leaders of the organization to confuse us, "the enemy," or a crude attempt to forge tactical gains from among the consequences of strategic-level attacks. In any event, the higher-level nonrational demands, or endstate, overshadow the lowerlevel demands, and we can conclude that the group is fundamentally - from our point of view ${ }^{17}$-nonrational, or at worst and for practical purposes, a sui generis modification of this category.

Logically if we therefore decide that there does in fact exist a new type of threat, one whereby a nexus has been created between the desire to be a terrorist and the desire to cause as much damage as possible, that hyper-terrorism can exist only in the case of nonrational actors, the obvious question should be: Are we in possession of the requisite tools to fight this new form of political violence? As individual nations, based upon traditional nation-states structures and concepts we are not.

\section{The Westphalian Inheritance}

It is often far too easy to take for granted the system of governance and administration in which we live today. If one does not professionally study modern history, or the evolution of international law, one could be forgiven for thinking that the current system of independent nation-states has existed for much longer than it in fact has. Its evolution is quite recent, in historic terms. Most commentators consider the Peace of Westphalia (1648) is considered as introducing the foundations for the creation in the West of a system in which the main actors were states, bodies with independent internal affairs - but which could ally with one another. In the Westphalian system, sovereignty would eventually become paramount. ${ }^{18}$ Later, as this concept evolved

17 It is again important to note that the categorization of rational or nonrational refers to "our" point of view. There exists, undoubtedly, in the mindset of the Aum Shinrikyo or al Qaeda operator, a distinct logic all his or her own. The difference is whether or not the desired endstate is posited in reference to a transcendental reality. As a result one could also use, as I have, the labels "political" and "transcendental" terrorist.

18 In fact, it was the sacrosanct nature of sovereignty that lay behind the creation of the balance of power system so important to Europe in following centuries. 
and as the individual allegiances of the people shifted from local landowner and royal house to professional political elites defined around a national identity, the state would evolve further into the now-commonplace nation-state, with its fundamental aspects of citizenship and nationality. ${ }^{19}$

For our purposes, the most important side-effect of the founding and development of the nation-state as a way to run and define a territorial unit are the ramifications of this new locus of sovereignty on the practice of providing for the security. While humans have been waging war for as long as territory and other forms of expropriable wealth have existed, the modern method for securing the nation-state resulted in a universal division of labor being replicated in practically every nation of the world. ${ }^{20}$ The national security systems thus created were quite simply formed around a categorization of threats as being either external, internal, civilian, or military in nature. Since the threats were all relatively discrete in scientific terms (i.e., easily definable and differentiated), it was logical to make the responses reflect the given challenges. If the enemy state wishes to obtain sensitive information of a military nature, then "we" should have a capability to protect such information and to capture its agents. Likewise, if the enemy state intends an act of military aggression, then "we" must maintain a permanent capability to deter such an attack or to meet it head on with force, and so on. Of course, particular variations developed-nations that combined civilian and military counterintelligence into one body, for example-but on the whole, the majority of modern nation-states established a division of labor. (For Detailed Information Please See Original Version of this Article.)

In each case, as the nation-state evolved and solidified its structures, the internal architecture of national security was reinforced by the laws and constitutional measures that defined the responsibilities and specific missions of the given organs. As a means to preserve efficiency and to ensure against abuses of power and information, practically every state of the developed West would severely demarcate the spheres of authority of each body. Matters of military intelligence, for example, were to be the sole purview of the body (or bodies) expressly mandated to respond to this threat, and so on. In fact, any intentional or even inadvertent negation of this division of

19 For a much lengthier and most influential discussion of the evolution of the nation-state, security, and international law, see the recent writings of Philip Bobbitt, especially his book The Shield of Achilles: War, Peace and the Course of History (New York: Alfred A. Knopf, 2002).

20 There are, of course, rare exceptions to the rule, such as Andorra or Costa Rica, but these all have in common either that they are too small to have their own armies or security services, or that they rely upon external and comprehensive guarantees of safety (as in the case of Costa Rica and its treaty relationship with the United States). 
labor would, if found out, generally cause scandal and/or investigation. ${ }^{21}$ This strict interpretation of missions and the resultant mirror-image response whereby the threat would be matched by a similar domestic body, would simply be further reinforced by the cut and dry, unequivocal threat environment presented by the Cold War.

\section{Matching Threats to Capabilities in the Third Millennium}

Whether or not one agrees with the still-influential theses cited earlier of Clash of Civilizations or The End of History, it seems clear that there has been at least one incontrovertible change in the geostrategic environment in which the developed countries of the West now find themselves: The Westphalian system's core presumptions no longer hold.

First, it may have become trite to say so, but that does not lessen the veracity of the statement that democracies do not wage war on one another. In fact, this tenet has in recent years been raised to the level of being a basic element of US foreign policy. Translated into more practical terms, it means that the countries of the western community of nations do not pose a threat to one another. This seems an uncontroversial statement since it is hard to envisage a classic nation-on-nation conflict involving the recognized tools of war erupting between Germany and the United States, or the United Kingdom and France. This fact is underpinned by the nature of new threats that have been identified in recent years. (For Detailed Information Please See Original Version of this Article.)

While this statement seems perhaps obvious, its ramifications in practical terms are highly significant. As we have seen, the national security architecture universally established under the Westphalian system and reinforced by the Cold War was not a multifarious tool. It was originally designed exclusively to deal with external threats that were in the form of (enemy) nation-states. The ultimate purpose was to prevent or win an armed conflict against another country or group of countries, usually in relatively close physical proximity to one's own nation. Today, the transatlantic area is constituted by nations that do not hold grudges against one another that could reasonably lead to an armed conflict for territory or wealth. In fact, continental Europe is now for the most part represented by an institutional form of integration that represents the largest voluntarily unified market and trading bloc the world has ever seen. ${ }^{22}$

21 One such example is when the CIA was accused during the Vietnam War of collecting information on American nationals in the United States - an activity that was mandated to the FBI.

22 For a discussion of the nature of the European Union and how its identity has fundamentally changed with the last round of enlargement this year, see the author's paper entitled "European Union Enlargement: Common Challenge or Internal Divide?" as presented to the German- American Fulbright Commission's Berlin Seminar: "Where Continents Meet," 20 March 2004. 
Thus, both the NATO and EU communities consist of nations whose national defense and security structures are wholly out of step with the danger they actually facedangers that are without borders, capitals, or nation-state-derived governments.

\section{Managing the Disjunction: Going "Super-Purple" and International}

With the bombing campaign against Serbia in 1999 and the more recent invasion of Iraq in 2003, some commentators have stated that the whole Westphalian system has suffered a death blow. The sacrosanct nature of a country's sovereignty-irrespective of domestic events-was held previously to be the core operating tenet of the system. The idea that internal behavior deemed by one or more countries as going against the fundamental norms of human rights justifies military action by an otherwise unaffected party, or parties, is truly novel. However, it is important to note that this undermining of national sovereignty is very much limited to those states that can be classified as "failed" or "rogue" in nature. As a result we should posit that the principle of unadulterated sovereignty still applies in the community of developed market democracies.

Nevertheless, when it comes to ensuring the security of these nations, there is a clear disjunction. For centuries the tools of national security matched the threat. Today the threats operate in a milieu that is transnational and not limited by the shell of nation-state architecture. Our foe today moves in a world that is unrestricted by international convention, by physical borders, or the dictates of government. Yet, the successful members of the transatlantic community that won the Cold War inherited a tool box of means to provide for security that has not changed and is very much still bound to the architecture of the Westphalian nation-state. Armies and police forces still serve countries. They are funded out of national budgets and are controlled by national governments. While the enemy has moved to a higher plain of existence we have not and will likely never do so, since world governance is not something that is welcomed either by the majority of citizens who find their identity in the nation-state metier, nor by the entrenched stratum of politicians who would have everything to lose should their domestic authority be replaced by a higher transnational one.

As a result we must look elsewhere for a solution. If we recognize the fact that our internal national security and defense structures were inherited from another age and for another purpose, yet we are unable for various reasons-above all political- to create supranational solutions, then the only viable option is to radically reform the nation-state level instruments so as to make them more applicable to the new tasks at hand, to closer resemble the enemies of today. This means admitting the fact that the old division of labor is out-of-date and that we cannot justify the maintenance of hermetic seals between various agencies and forces. The internal barriers between the police force, the army, and various intelligence services must at least be in part 
dismantled so as to facilitate a modus operandi that is as flexible and as effective as that of our new enemies. This would result in the creation of "Super-Purple"23 structures as flexible and hypermobile as the enemies they needed to neutralize. It would not even be too far-fetched to make the argument that many countries in the current geostrategic environment would be best served by a unitary body conglomerating all the skills of the various separate agencies and units into a new structure better suited to addressing threats like al Qaeda and transnational organized crime syndicates. ${ }^{24}$ There even exists a national counterterrorism precedent for such a unified multiagency approach. ${ }^{25}$ Such examples must be revisited and expanded internationally to follow the principle and vision laid out by Dr. Boaz Ganor (detailed later in this book).

Even so, the reality is that such a broad, sweeping reform and restructuring of the national security apparatus of the nations of the developed West will inevitably run into heavy resistance from all those who have an interest in maintaining existing

23 "Purple" operations and structures are those that involve all the arms of military service, army, navy, air force, and marines. The US Department of Defense has been emphasizing the "Joint," or "Purple," mode for some years now, breaking down the technical as well as mental barriers to interoperability among the services. My proposal would take this approach and apply it across the whole national security structure, not just the armed forces. I am indebted to my good friend Keith Mines of the US State Department for christening my concept so aptly, "Purple" referring to the slang for joint operations (arrived at when the service colors are mixed), and "Super-Purple" referring to interdepartmental and international jointness.

24 Lest the reader think I am making an argument here for states to follow the US model by creating their own Department of Homeland Security (DHS), I am not. The gargantuan DHS, which brings together over twenty agencies and two hundred thousands federal employees under one letterhead, is not a radical, new multidisciplinary approach, but represents just one more layer of bureaucracy that in its size and functioning reflects a distinctly Cold War approach as opposed to one that reflects the flexibility of, say, an al Qaeda.

25 In the bloodiest years of the PIRA's campaign against the UK government, the decision was taken to create a radically new unit that would take the fight to the most dangerous players. Variously called, 14 Intelligence Company, 14 Int., or "The Det," this formation employed units made up of local police officers, members of the Special Forces (SAS/ SBS), and the intelligence services. 14 Company was very good at its job, overcoming the old divisions and obstacles to effective interagency cooperation. Unfortunately it was too good at its job, being responsible for the deaths of many IRA terrorists and doing so in a way that was unsanctioned in the broadest political sense of the word. As a result, the unit was disbanded. While information on this part of the PIRA/UK struggle is limited, some works have in recent years shed light on 14 Company. See, for example, Martin Dillon, The Dirty War: Covert Strategies and Tactics Used in Political Conflicts (New York: Routledge, 1999). 
structures and who do not see the necessity for change. Therefore, it is most likely the responsibility of the nongovernmental think-tank community to promote the initial discussion on how best to shape old capabilities to meet new threats and to convince as many members of the general public as possible that the topic should be placed on the political agenda of the various nations. For if we do not begin to discuss and then eventually effect change, the West will continue to suffer in a deadly game of "catchup," as those unfettered by limits of the nation-state proceed to exact damage upon our countries and way of life.

In the meantime, the Marshall Center's Program on Terrorism and Security Studies represents the first and most successful example of the "Super-Purple" approach as applied to the creation of an international network of counterterrorism professionals. As the international and interdepartmental connections built through this program grow ever deeper and wider, it will become easier and easier to eventually institutionalize international jointness and thus take the fight most effectively to an enemy that already thinks and operates in the "Super-Purple" mode.

Dr. Sebastian L. v. Gorka Dr. Sebastian Gorka is an internationally recognized authority on issues of national security, terrorism, and democratization, having worked in government and the private and NGO sectors in Europe and the United States. A graduate of the University of London and Corvinus University, Budapest, he was Kokkalis Fellow at Harvard's John F. Kennedy School of Government and holds a Ph.D. in political science. He was the first Director of the Institute for Transitional Democracy and International Security, and also spent four years as Adjunct Professor for the PTSS program of the Marshal Center. Dr. Gorka has published in excess of 120 monographs, book chapters, and articles, many for the JANES Group of the UK and appearing in the Financial Times, the BBC, CBS, REUTERS, the Washington Post, EuroNews, and Newsweek. Dr. Gorka advises and briefs the US Special Operations Command and NATO; recently he advised the Pentagon on Secretary Gates' draft guidance on strategic communications in the war on terrorism. Dr. Gorka is a frequent lecturer at institutions such as the FBI's International Law Enforcement Academy, USMA West Point, and the School of Advanced Military Studies, Fort Leavenworth. He teaches in the Irregular Warfare Department, College of International Security Affairs, National Defense University, Washington. 


\section{Recommended Readings}

Aldis, Anne, and Graeme P. Herd. The Ideological War on Terror: Worldwide Strategies for Counter-Terrorism. London: Routledge, 2007.

Benjamin, Daniel, and Steven Simon. The Age of Sacred Terror: Radical Islam's War Against America. New York: Random House, 2003.

Byman, Daniel. Deadly Connections: States that Sponsor Terrorism. Cambridge: Cambridge University Press, 2005.

Connelly, Matthew. A Diplomatic Revolution: Algeria's Fight for Independence and the Origins of the Post-Cold War Era. Oxford: Oxford University Press, 2002.

Gorka, Sebastian, and David Kilcullen. "Al Qaeda and US Strategic Communications." Meeting summary for Interagency Strategic Communication Fusion Team, 23 January 2009.

Harmon, Christopher C. "Public Diplomacy's Next Challenge," Connections, Vol. 7, No. 1 (Spring 2008), 141-153.

Jensen, Richard Bach. "The International Campaign Against Anarchist Terrorism, 1880-1930s." Terrorism and Political Violence, Vol. 21, No. 1 (January-March 2009), 89-109.

Kissinger, Henry. Diplomacy. New York: Touchstone Books, 1995.

Laqueur, Walter. The Age of Terrorism. Boston: Little, Brown \& Co., 1987.

Satloff, Robert. The Battle of Ideas in the War on Terror: Essays on US Public Diplomacy in the Middle East. Washington, DC: Washington Institute for Near East Policy, 2004.

White House. National Strategy for Combating Terrorism. Washington, DC: Government Printing Office, September 2006. 


\section{Bibliography}

Fukuyama, Francis. The End of History and the Last Man., 1992.

Huntington, Samuel. The Clash of Civilizations and the Remaking of World Order. New York: Simon and Shuster, 1996.

Dillon, Martin. The Dirty War: Covert Strategies and Tactics Used in Political Conflicts. New York: Routledge, 1999.

Aldis, Anne, and Graeme P. Herd. The Ideological War on Terror: Worldwide Strategies for Counter-Terrorism. London: Routledge, 2005.

Daniel, Benjamin, and Steven Simon. The Age of Sacred Terror: Radical Islam's War Against America. New York: Random House , 2003.

Byman, Daniel. Deadly Connections: States that Sponsor Terrorism. Cambridge: Cambridge University Press, 2005.

Gorka, Sebastian, and David Kilcullen. Al Qaeda and US Strategic Communications In Meeting summary for Interagency Strategic Communication Fusion Team., 2009.

Harmon, Christopher. "Public Diplomacy's Next Challenge." Connections 7, no. 1 (2008): 141-153.

Jensen, Richard Bach. "The International Campaign Against Anarchist Terrorism, 18801930s." Terrorism and Political Violence 21, no. 1 (2009): 89-109.

Kissinger, Henry. Diplomacy. New York: Touchstone Books, 1995.

Laqueur, Walter. The Age of Terrorism. Boston: Little, Brown \& Co, 1987.

Satloff, Robert. The Battle of Ideas in the War on Terror: Essays on US Public Diplomacy in the Middle East. Washington, DC: Washington Institute for Near East Policy, 2004. 